\title{
Jinnah, Pakistan, and Islamic Identity
}

\section{By Akbar S. Ahmed. Routledge, New York, 1997, 274 pp. + xxix.}

Dr. Axbar S. Ahmed is probably the most published author in Pakistan. His published works, some of which have earned excellent reviews, make a formidable list. As perhaps the best known contemporary Muslim anthropologist, his commitment to the discipline, despite his avocation of being an administrator, is the key to his success. What sets Ahmed apart from most Pakistani authors is that his writings are informed by theoretical considerations and anchored in empirical data. He exudes easy familiarity with methodology, is creative and imaginative in his approach, and can conceptualize. Moreover, he can intellectualize problems and issues. As with his earlier writings, his present work is marked by these characteristics. 
The work is structured around one major theme (Jinnah), and the subthemes of the nature of nationhood, Islam, ethnic and religious identity, the problems of minorities, and the pervasive and ubiquitous influence of media, race, empire, and other factors. Using the methodologies of cultural anthropology, semiotics, and media studies, Ahmed explores old ground with new insights and interpretations. What we have here is neither biography nor history per se; it is part biography, part history of partition, an exploration of Muslim nationhood and Pakistani statehood, and part the Muslim search for identity, a quest that not only inspired the Muslim struggle for Pakistan during the 1940s, but which is still relevant (e.g., northern Cyprus, Bosnia, Chechnia, Kashmir, Kosovo, Mindanao [the Philippines], Pattani [Thailand], and even for the Turkish minority in Bulgaria).

All said and done, it was the critical problem of identity to which Jinnah addressed himself in the Indian context of the 1930s and 1940s. Thus he represents not only Pakistan, but also a manifestation of the very search for identity in the present larger Muslim world context. His solution to the problems of marginalization, alienation, and even exclusion of Muslims from the corridors of power serves as a beacon to Muslim communities struggling for identity, self-expression, and self-realization. Hence the relevance of Jinnah to the modern Muslim world.

Ahmed organizes his somewhat disjointed material and manages to weave together the disparate topics in eight chapters, along with an introduction and an epilogue, spread over 300 pages. The Introduction argues the case of Saladin (Șalăh al Dĩn, the conqueror of Jerusalem) as an ideal Muslim hero, asserting that "contemporary Muslims everywhere look for Saladin" (p. xvii). Ahmed uses Saladin as "a metaphor, a cultural context," and draws "an analogy ... between Saladin and Jinnah."

Chapter One discusses the people who mattered to Jinnah, while the Chapter Two outlines the Subcontinent's history, focusing on the developments that made Jinnah's movement possible. Jinnah's conversion from an "ambassador of Hindu-Muslim unity" to the fiercest advocate of Hindu-Muslim separation, "a slow and inevitable process," is discussed in chapters Three and Four. Next comes Mountbatten's role as the last Viceroy and the first "Paki-basher," who constricted, thwarted, and disabled Pakistan from becoming a viable concern upon independence in August 1947. Chapter Six focuses upon Lord and Lady Mountbatten's relationship with Nehru and its bearing on both Mountbatten's policies and predilections as well as on Jinnah. Here, for the first time, a (usually ignored) topic that is crucial to understanding the Viceroy's moves and motives and the somersaults he enacted during the critical partition period is discussed rather explicitly: the long drawnout, intense love affair between Edwina and Nehru, its wide-ranging political ramifications, and its possible direct and indirect effects on decision making during the summer of 1947. Chapters Seven and Eight discuss the creation of Pakistan and its subsequent history, the sort of Islamic identity that Jinnah envisaged for the fledgling state, his relevance to modern-day Pakistan, the bleak Muslim situation in India (from Anandmath [1882] to Ayodhya [1992]), and the struggle for identity in Bangladesh. Finally, the Epilogue stresses the urgent need for dialogue, reassessment, greater Indian-Pakistani and Hindu-Muslim harmony "if you are not to be locked in eternal confrontation." Also suggested are steps for improving understanding and facilitating dialogue. Reconciliation, understanding, and sorting out differences and strengthening common ground are recommended.

What sets Ahmed apart from most of Jinnah's biographers is the historical perspective and the human angle he brings to his discussion. Wolpert, says Ahmed, fails to explore "Jinnah's rediscovery of his own roots, his own sense of identity, of culture, and history, which would come increasingly to the fore in the last few years of his life" (pp. 24-25). “Ayesha Jala's portrayal of Jinnah ... half machine, half man. Jalal's Jinnah is a robot, programmed to play poker for stakes ... and win in small committee rooms; and like 
a machine does not even appear to believe in what he is doing...." She also fails to "explain how he linked up intellectually with Sir Sayyed and Iqbal in the quest for Muslim unity" (p. 30).

In contrast, Ahmed's main contribution lies in his focusing on the cultural transformation that Jinnah underwent in 1937, a transformation that other Muslim leaders (e.g., Sir Sayyed, Iqbal, and Hasrat Mohani) had gone through earlier. Indeed, 1937 represented a watershed in Jinnah's public life. Hence, argues Ahmed, Jinnah's "genius was, apart from his recognized talents as a political strategist and constitutional lawyer, to encourage the development of a modern Muslim persona, one which would represent a modern Muslim nation and reflect its spirit while providing identity and unity" (p. 71). As against the standard Pakistani portrayal of Jinnah as a cardboard character, projecting him as a "stiff formal lawyer ... stuck to his Western dress and Western ways," shunning mass rallies, stern, unfeeling, and emotional, Ahmed reveals the leader's human face. Interestingly, he is the only author to have talked to his daughter, Dina Wadia.

To Ahmed, Jinnah is not the "secular" leader of the first avowedly Muslim nationstate, but rather the universal symbol of Muslim identity. Along with Sharif al Mujahid (Jinnah: Studies and Interpretation, 1981), Ahmed is the only major author to stress the fact that foremost in Jinnah's vision was "the unequivocal Islamic nature of Pakistan, drawing its inspiration from the Qur'an and the holy Prophet. This is the vision of an Islamic society which would be equitable and compassionate and tolerant ..." (p. 177). In his reply to Mountbatten's address during the transfer-of-power ceremony on 14 August 1947, Jinnah underlined his preference for the Islamic model when he told Mountbatten that a more permanent and more inspiring model to follow than the Prophet could not be found, thereby ignoring Mountbatten's choice of Emperor Akbar for that particular role.

As in the case of his other publications, Ahmed displays certain chinks in his armor. First, the subtitle ("The Search for Saladin") is rather misplaced. For one thing, it does not conform to the ground reality in terms of Muslim India's national consciousness during the 1920s, 1930s, and 1940s. During that time, Mustafa Kemal, and not Saladin, was the hero. Muslims of those years fed incessantly on Kemal's exploits from Galilee (1916) to the battle of Sakarya (1921) on the road to Ankara (which ensured the eviction of the invading Greek army from the Turkish homeland), and were enthralled by his stout defiance of the West, his singular success in shredding the iniquitous Treaty of Sèvres (1921) and replacing it with the Treaty of Lusanne (1923), which was negotiated with the principal Allied power on a footing of equality.

To this generation, Kemal had aborted long-term Allied plans to partition Așia Minor, push the frontiers of Europe into the Middle East, and recreate the Mediterranean as a European Mare Nostrum. Jerusalem had been reoccupied by Lord Allenby's forces in 1916, due in part to the Arab Rebellion against the Ottomans, and the legendary Saladin was a rather hazy figure, much too distant in the past. In contrast, the Sublime Porte represented Islam's mundane strength and glory in immediate terms, and Kemal, who had saved it for Islam, had adorned the front pages of Muslim papers throughout the Subcontinent since the Turkish "war of liberation" (1919-22). A good deal of literature, especially in Urdu and Punjabi, was produced about him, and most Muslim petty shops in both small and large towns displayed his portrait until it was replaced by the new, emerging "savior," Mohammad Ali Jinnah, in the late 1930s.

Kemal was, therefore, more real, more inspiring, and more relevant in early twentieth-century Muslim consciousness and setting. Despite his abolition of the caliphate (1924), his opting for laicism and wholesale Westernization, and his abandonment of the Muslim East, Kemal was still hailed as ghâzī (a successful warrior) and sayf al lslām (the sword of Islam). Above all, he was considered the chief propelling force toward "the 
development of a modern Muslim persona, one which would represent a modern Muslim nation and reflect its spirit while providing identity and security." The national flag and the national anthem represent the most emotive and most telling symbols of a nation's persona, and though both were oriented toward Islam (especially the anthem composed by the Islamicist Mahmet Akif), Kemal retained them, thereby acknowledging in a sense the Islamic legacy inherited by the modern Turkish nation (compare this to what Nasser and Qassem did in Egypt and Iraq, respectively). Jinnah admired Kemal and considered him "a great hero" and "an inspiration... [for] the Muslims of India." Jinnah reportedly advised his daughter to read Armstrong's Grey Wolf while at Hampstead in the early 1930s. As one who grew up in a politically orientated family during the $1930 \mathrm{~s}$, I know that the model was Kemal and not Saladin, and that the search was for another Kemal and not another Saladin. In the reviewer's view, both the subtitle and the cultural metaphor matrix are extraneous and could be dropped.

Second, Ahmed's portrayal of the Iqbal-Jinnah relationship is, of course, good copy but bad history. Ahmed would have Jinnah "acknowledge Iqbal as his mentor" (p. $73 \mathrm{ff}$.) In his Foreword to Letters of Iqbal to Jinnah (1943), Jinnah acknowledged Iqbal's contribution:

His views were substantially in consonance with my own and had finally led me to the same conclusion as a result of careful examination and study of the constitutional problems facing India, and found expression in due course in the united will of Muslim India as adumbrated in the Lahore resolution... (p. 5; italics added)

This acknowledgment by no means makes Iqbal his mentor, but popular Pakistani bazaar version does. Iqbal was a poet and visionary given to flights of imagination, while Jinnah was a born pragmatist, a seasoned and practical politician who sought to keep his feet firmly on the ground all the time. Thus Jinnah, in one of his letters to Iqbal, countered the latter's suggestion to declare Muslim India's political objective immediately and unequivocally: "I want to pull them [Muslims] up step by step and before making them run I want to be sure that they are capable of standing on their own legs" (Pakistan Times, 25 December 1955). The spectre of "the passing of the flame from one to the other," depicted by Ahmed, also is not grounded in history but rather is the handiwork of the author's fertile imagination. It is rather intriguing that Ahmed succumbed, though unwittingly, to a simplistic approach, an approach of which he so rightly accuses most Pakistani authors.

In terms of format, Ahmed characteristically goes in for the "big picture," a large landscape, and generalizations galore. Such a method provides breadth but, unless handled dexterously, comes with certain costs in terms of depth and a slide toward a procrustean-bed approach. The work explodes with an array of provocative ideas, but, although not inexplicably, without adequate linkages at certain places. A plethora of subthemes makes the work multidimensional. However, an omnibus approach also may tend to make it somewhat disjointed, fragmented, and repetitious (e.g., pp. 71, 98). The work also features some errors of facts and dates (e.g., pp. 103, 111, 113). Clearly, this work should have been edited more meticulously in order to make the narrative more compact, consistent, and coherent.

Despite the serpentine trees and a dense and entangled foliage, the grand view is simply fantastic. This is what one should really look for in a significant work like this. Indeed, in terms of the much needed reassessment of Jinnah's work and significance, Ahmed represents a singular contribution. And in "revealing Jinnah's human face alongside his hero- 
ic achievement," Professor Francis Robinson says, the present work makes Jinnah "accessible to the current age and renders his greatness even clearer than before." It is a work that could be read and commented upon for a long while, and that could inspire a fresh look at Jinnah, especially in terms of his significance in the modern Muslim world context.

Sharif al Mujahid

Karachi, Pakistan 